\title{
La Révolution française
}

Cahiers de l'Institut d'histoire de la Révolution française

$8 \mid 2015$

Entre la Révolution et l'Empire : une nouvelle politique dans l'océan Indien

\section{The Influence of Liberalism in the Definition of the} Idea of the Nation in India

\section{Elena Valdameri}

\section{(2) OpenEdition}

\section{Journals}

Electronic version

URL: https://journals.openedition.org//rf/1333

DOI: $10.4000 /$ Irf.1333

ISSN: 2105-2557

\section{Publisher}

IHMC - Institut d'histoire moderne et contemporaine (UMR 8066)

Printed version

Date of publication: 23 June 2015

\section{Electronic reference}

Elena Valdameri, "The Influence of Liberalism in the Definition of the Idea of the Nation in India", La Révolution française [Online], 8 | 2015, Online since 24 June 2015, connection on 07 December 2022 URL: http://journals.openedition.org//rf/1333 ; DOI: https://doi.org/10.4000/Irf.1333

This text was automatically generated on 29 September 2020

All rights reserved 


\title{
The Influence of Liberalism in the Definition of the Idea of the Nation in India
}

\author{
Elena Valdameri
}

\begin{abstract}
"Freedom is not merely the elimination of foreign rule. To equate it with merely the recovery of our national independence is to forget its more positive aspects, more especially social and economic freedom, freedom of thought, the ensuring of our liberties in general, the possibility of a rich, varied and full life for the individual."

K.M. Panikkar, The State and the Citizen ${ }^{1}$
\end{abstract}

\section{Introduction}

1 The purpose of this essay is to highlight how during the nineteenth and the first decade of the twentieth century, in their search for freedom, educated Indians appropriated and reshaped certain principles and values of the civilisation of their colonisers, the British. In particular, I will try to explain the meaningful role played by liberalism in dealing with the Empire and with the status of colonised in the Indian context. In doing so, I will take into account Giorgio Borsa's theory of modernisation ${ }^{2}$, according to which, the phenomenon of re-working the key aspects of the thought of European and American liberals was part of a wider, complex process of transformation of the Indian society that the Indian intelligentsia undertook in order to challenge the hegemony of the British Raj. In making this effort, Indians accepted some of the Western ideologies and political theories that they regarded as essential elements of modernity. But the exogenous principles and values had to be combined with the indigenous ones in order to be legitimised. In other words, the acceptance of the 'modern' world needed to be blended with Indian 'tradition' and culture so that the model of modernisation over- 
imposed by British colonialism could be challenged and a process of modernisation that had autonomous characteristics could be set in motion. Thanks to this creative synthesis, a distinct identity from the one of the colonisers was created and different ideas of the nation in the modern meaning of the sense were formulated. Thus, according to the varying combinations of Indian and European ideas, the conceptualisation of the nation could be progressive, open-mined, embracing new values and envisioning a secular state and society or, on the contrary, it could be conservative, sectarian and rejecting Western values a priori. As I will attempt to show, when some Indian nationalists incorporated liberal ideas in their thought in the light of their tradition and cultural experience, they elaborated a new form of liberalism, that emphasised collective identity and equality more than British liberalism did. Therefore, against some current critiques that easily dismiss it as a mirror image of the ideas of the British liberals, Indian liberalism contributed to give India a system of values that were conducive for the construction of a pluralistic society and eventually of democracy. In the last part of the essay, Gopal Krishna Gokhale's thought is chosen as a significant example to understand the importance that some of the nineteenth-century Indian nationalists attributed to certain Western values and to show how what was imparted by the British as a mask of conquest could be adopted by the Indians as a means to grasp, and then condemn, the colonial order.

\section{Liberalism today}

2 As the eminent Italian historian Benedetto Croce maintained, history is always contemporary history: our interest in the past generally originates from the will to understand the problems of the present we are living $\mathrm{in}^{3}$. It is in this light that the new attention kindled by liberalism is explainable. In a world extensively affected by the neoliberal ideology, questioning the role of liberalism and its influence in the course of history becomes quite natural to the scholar. Being liberating and limiting at the same time, on the one hand claiming the freedom of the individual and on the other hand fostering the acquisitive and possessive nature of that same individual, liberalism has always attracted very strong likes and dislikes and has been equally attacked by the right for being too extreme and by the left for not being radical enough.

Today, because of its stress on individualism and freedom vis-à-vis equality, liberalism is often perceived as the ideological antecedent of the present unjust social order. Due to its past exclusionary stands to the detriment of lower classes, liberalism is accused of having been expression of the upper strata of society; again, in the ex-colonies it is seen as the ideological 'cover' which allowed the imperialistic status quo to be preserved. In a nutshell, it has become almost a commonplace to dismiss liberalism as something superficial, a mask for the hegemony of the privileged classes, if not as a ploy to horizontally spread Western dominance over the rest of the world. The fact that over the past thirty or forty years political and economic liberalisms became to an increasing extent fused in the form of neoliberalism made liberalism and equality seem even more mutually incompatible. But sweeping generalisations that blame the contemporary neoliberal circumstances on liberal ideas overlook that, in the course of history, the relationship between political and economic liberalisms has not been constant. So, for example, in the first half of the twentieth century, various strands of liberalism included both individual and social concerns and were able to accommodate 
a certain amount of social equality. Although sharing the same historical roots, liberalism and neoliberalism should be distinguished, in order to counter the ideological argument that the latter is the revival of the former. As a matter of fact, the main difference between the two ideologies is that neoliberalism has never been conceived as a liberating project. The ideology of neoliberals, who often distinguish themselves for being sceptical of democracy, has retained only the economic liberal ideas; on the contrary, it has not incorporated the most emancipatory elements of political liberalism, as indicated by the fact that it is increasingly linked with the authoritarian use of state power.

4 It is undeniable that, since the beginning, liberal ideas presented terrible contradictions and, for a long time, were not concerned with the expansion of democracy to the the lower social classes and women, or with the extension of freedom to 'backward peoples'. However, this is not a good enough reason for rejecting liberalism in toto and letting it disappear in the shadow of the dominant neoliberal ideology. It is, in fact, misleading to consider liberalism as something immutable in the course of time: liberalism developed across four hundred years of human history, during which it had to come to grips with different political problems, according to the historical period and to the cultural peculiarities of the countries in which it grew. Even when the socio-political conditions were similar, the responses that liberal thinkers gave to the same problems were different, and sometimes contrasting. Several scholars have even wondered whether liberalism rather than being considered a unified ideology, should not be seen as a set of different, although parent ideologies. This is a position which is based on the perception of how labile are the outlines and variable the premises of liberalism as an ideology. Yet, if it is certainly a mistake to see liberalism as a homogenous bloc and not to take into account its specificities in the different historical contexts, it would be equally wrong not to emphasise what the several liberal currents have in common. For liberalism, as Norberto Bobbio maintained, is predicated on the assumption of the Enlightenment philosophy that the individual, the rational being, has inalienable and indefeasible rights that the state must not violate ${ }^{4}$. Ergo, the various strands of liberalism share a common denominator: the desire to safeguard the innate right of the individual against political power. This principle cannot be easily thrown in the garbage dump of history, since it had a major impact on several societies at different times and keeps being a relevant source of action and thought.

5 Nevertheless, the fact that liberal ideas remain a live question today is not always acknowledged. On the one hand, liberalism is positively evaluated and regarded as a vitally-needed political and doctrinal element in the history of humankind ${ }^{5}$. On the other hand, liberalism is rejected as the real culprit for past and present global injustice. In particular, some criticism of the liberal ideology is in tune with certain 'postmodern' approaches which reduce universal and non-negotiable values such as democracy, human rights, promotion of reason, tolerance and progress to the level of relative values. These principles are ridiculed as 'imperialist categories' only because they were initially formulated in Europe. Liberalism is thus seen as the ideological 'cover' for imperialism and inequality. Yet, such currents of thought are unconvincing for two main reasons. From the political point of view, they can be very dangerous since they deny the possibility of building societies predicated on universal human rights. And this signifies the negation of what Hobsbawm called "the project of the eighteenth century Enlightenment ${ }^{6 \text { ", }}$, that is the renunciation to the most liberating 
aspects of liberalism. From the historical point of view, these trends deny the fact that, in some circumstances, liberal ideas offered a powerful critique of imperialism and turned into an ideological instrument of resistance.

\section{Giorgio Borsa's theory of modernisation}

6 At this point, it is expedient to draw attention to India. Also in the Indian anglophone academic arena, some are not immune from treating Enlightenment and modernity as enemies to be deconstructed and displaced ${ }^{7}$. This stand is ascribable to the understandable fact that some Indian intellectuals consider a mission to substitute the Eurocentric vision of history with an Asiacentric one ${ }^{8}$. Nonetheless, if some of the nationalist and marxist historians' arguments ${ }^{9}$ challenge certain orientalist historiographical stereotypes that persist in European and American academia and that see Westernisation as the only acceptable model of modernisation, the main weakness of the Asiacentric approach is that it corroborates the dichotomisation of the world in 'West' and 'East'. This makes difficult to understand the origins of the modern world and, moreover, to see how the cultural and intellectual connections between the several parts of the globe have developed in the course of history.

7 For this purpose, Giorgio Borsa's theory of modernisation, although initially formulated about fifty years ago, remains a very useful intellectual instrument and interpretative model to explain the history of the transformation of Asian societies as the outcome of the encounter with European civilisation through colonialism ${ }^{10}$. According to Borsa, from a certain point onwards, modernisation in India, and more generally in Asia, was not an external imposition. Instead, it became a conscious will, an endogenous process motivated by the need to elaborate an indigenous idea of modernity. Therefore, the modern world was the result of two dialectic moments: on the one hand, European domination and, on the other hand, the Asian reaction to it ${ }^{11}$. So, modernisation was seen by Borsa as a process of exchange and interaction and not as a phenomenon that, originated in Europe, reproduced itself identically in the civilisations with which it got in contact. In other words, this view rejects the argument - still very popular in certain academic environments - that modernisation is inherently European, an expression of the Western civilisation and, as such, it manifested itself always and everywhere with European characteristics. For modernisation is not a "liquid"12 that can be transferred from a civilisation to the other, since it acquires local cultural peculiarities according to the historical experience and cultural background of the different civilisations of the world.

8 Hence, in the light of such theory, it becomes clear that, against certain biased historiography, to regard 'East' and 'West' as divided and opposed does not contribute to investigate the intellectual history of India: such a perspective underestimates the history of political thought, for it would be very difficult to explain its role in colonial India if not as a process of fruitful combination of ideas coming from different intellectual strands. In fact, as Sanjay Subrahmanyan explains Indian history can be easily described as "a crossroads, where not only did regions and regional cultures influence one another, but things came and went from far more distant lands, whether Europe, Central Asia and East Africa ${ }^{13}$ ". India was never sealed off from the rest of the world and its people, not differently from other peoples in the rest of the world, have always been "ready to assimilate anything useful that came from anywhere ${ }^{14 "}$. 
9 As a consequence of the penetration of British colonialism and the diffusion of the English language, the Indian intelligentsia came in contact with new ideas, towards which they adopted an open-minded approach. The European economic, political, judicial, cultural ideas and practices hastened the disintegration of the traditional society and spurred a process of transformation of which Indians were not passive objects. In fact, Indian intellectuals, under the impact of the Western culture appropriated themselves of new intellectual tools whereby they could rediscover, reassess, criticise, and reformulate their own cultural tradition. But this re-elaboration started from the awareness that, in order to transform Indian society, it was necessary to accept new values, principles, ideologies, and political theories. Among these, there were the ideas of the American and French Revolution such as nationality, liberty, unity, representative institutions, namely concepts that Indians increasingly perceived as universally desirable. At a later stage, the same ideas would be at the basis of the judgment condemning the modus operandi of the colonial regime and articulating the intellectual framework of nationalism.

The construction of Indian national identity, thus, originated from this compromise between 'modernity' and 'tradition': the results were different because the relationship between 'modern' and 'traditional' was mutable. Yet, all the ideologies that developed from such variable synthesis represented autochthonous and original ideas of modernity: they were far from being merely emulative. So, also the intellectuals that took an anti-modern and anti-British stand accommodated exogenous ideas in their ideology and advocated their own notion of modernity. In the same way, the formulation of the conceptualisation of the nation, irrespective of its foundations, was a modern phenomenon: it implied the 'rediscovery' of Indian tradition in the light of new ideas and new needs. The nation was defined in the modern sense of the term, drawing both from indigenous, 'traditional' elements and from European ones. But this process of adoption and adaption of the latter to the Indian context was not always acknowledged by the Indian ideologues, who often tried to show that elements of modernity had already existed in the Indian tradition, and then ideas coming from outside were redundant ${ }^{15}$.

11 Therefore, any schematic and homogenising interpretation of the factual and intellectual history of nationalism is not self-explanatory. Indian nationalism was always multifarious, for it was composed by several strands that envisioned different, often diverging, ideas of the nation. Depending on the particular blend of European and Indian ideas, the conceptualisations of the nation varied. For instance, while refusing Mazzini's violent methods, Gopal Krishna Gokhale embraced the libertarian and voluntaristic elements of the Italian thinker's idea of the nation and combined them with Indian traditional multiculturalism and the social reformism of the Maharashtrian liberals. On the contrary, Bal Gangadhar Tilak rejected the most liberal aspects of Mazzini's thought, whereas he adopted his cult of the nation and fused it with some Hindu and Vedic unifying myths: the result was a fusion of radical politics and social reaction. So, there were different and conflicting strands within the anti-colonial movement and, in contrast with what secular nationalist historians maintain, some were religious, community-based and discriminatory ${ }^{16}$. Thus, patterns of inclusion or exclusion, democratic or undemocratic principles, equality or disability are to be found in Indian nationalism from its beginning: since the nineteenth century, intolerant and exclusionary ideas of the nation were organic in Indian political discourse as much as 
liberal ideas of the nation. Even though there is no idea of the nation intrinsically more legitimate or authentic than another, the fact remains that these ideas can and must be judged by considering their social consequences in terms of peace, democracy, and inclusion. When, on the one hand, the Marxist and 'postmodern' views ${ }^{17}$ see the anticolonial movement as an altogether bourgeois phenomenon and, on the other hand, the nationalist historiography ${ }^{18}$ treats all Indian nationalists as saints, they attain an ideological reductio ad unum of the different conceptualisation of the nation. Further, since these ideas' different social consequences are swept aside, such historiographical perspectives hardly provide any explanation for the political and social crises of the last century of Indian history ${ }^{19}$.

12 Also the so-called Cambridge school interpretation does not help emphasise the significance and nature of the principles that informed Indian nationalism. In fact, the exponents of this distinguished historiographical school did not attribute any social relevance to the Indian 'middle class'. In their opinion, educated Indians had no autonomous political project, since they were acting as clients of powerful notables. So this interpretation reduced the ideas of the protagonists of the anti-colonial movement, deprived of any weight, to a political expedient for the realisation of the individual self-interest. As a result, the nationalist ideology, voided of any autonomy, was only an awkward imitation, nay, a travesty, of European nationalism ${ }^{20}$. Contrary to this argument, my contention is that the educated Indian 'middle class' had a notable social influence, since it became the carrier of a modern and rationalist outlook and, as such, was a crucial agent of modernisation. But in order to acknowledge this, a reevaluation of Indian intellectual history that shows, inter alia, the notable role played by liberalism in the evolution of Indian political thought, is necessary.

\section{Liberalism as a 'conjunctural phenomenon'}

Therefore, my essay wants to be a contribution to such works as those of Christopher A. Bayly, Sugata Bose, Andrew Sartori ${ }^{21}$. These confirm that the use of the liberal ideology in the subcontinent was a "conjunctural phenomenon rather than simply a lineage or influence diffused from Europe to Asia, from metropole to colony. It reflected attempts by people - not all of them elite - to grapple with the consequences of globalisation, the intrusion of colonial state and the collapse of embodied authority of popes, mandarins, or Brahmins which had all happened within a generation ${ }^{22}$ ". Such sophisticated works substantiate what Borsa maintained in the 1960s and 1970s, that is to say that ideas moved freely in the space of the Empire and Indians - but the same can be said of the inhabitants of other colonies - were not passive receivers of ready-made concepts and much less that the intellectuals in the colonies were clumsily aping their dominators. As a result, the old misconception of the 'centre' setting in motion a unidirectional process of change in the 'periphery' is disputed, since colonialism appears as a realm where mutual contamination and exchange were possible.

Nevertheless, note must be taken that the emphasis on globalism does not necessitate "circumvent[ing] the narratives of the nation and the Empire that have constrained scholarship and militated against the interrogation of ideas and their purposes within the South Asian context ${ }^{23}$ ". Rather, it draws our attention to the crucial role played by ideas in the conceptualisation of the different versions of nation as the intellectual and political tool for the liberation of the colonised. As a matter of fact, the adoption of 
liberal principles in the Indian context contributed to the definition of an inclusive idea of nation vis-à-vis an exclusive one. As seen above, the latter was as much informed by European and indigenous ideas as the former. Thus, the way in which liberalism was appropriated in British India is useful for understanding how it was adapted and utilised according to the needs of the Indian intelligentsia and how it served, at a later stage, not only as the ideological foundation for the anti-colonial movement, but also as a programme for social action against creed, caste and gender inequalities.

the violence always inherent in the building of Empires and, more specifically, in the 'power-knowledge' logic of colonialism. In fact, as Christopher Bayly has shown in his work Recovering Liberties. Indian Thought in the Age of Liberalism and Empire, the Indian context was utterly different from the European one and the starting point for the reflection on liberalism was the condemnation of state violence and not, as was the case in Europe, the problem of intellectual freedom ${ }^{24}$. An enlightening example is that the eminent Bengali thinker and reformer, Rammohan Roy, used to cite Grotius and other British liberal authors to decry the violation of treatises and the misappropriation of land by the East India Company ${ }^{25}$. Indian newspapers did not miss a chance to note that the strict censorship imposed over the native press was a practice quite opposite to the precept of freedom guaranteed in England ${ }^{26}$. Again, the introduction of self-government was demanded by Gopal Krishna Gokhale as a response to Lord Curzon's oppressive rule ${ }^{27}$.

Thanks to the diffusion of the 'imperial language' and the promotion of English education, not only were Indian intellectuals provided with a means of interregional consolidation and with a common platform of thought, but they were also included in an 'international public sphere'. Indians had realised much before the 1835 Bentick resolution that learning English was a extraordinary achievement, since it provided them not only with new opportunities of decent jobs in the colonial administration, but also with an interpretative key through which they could more readily make sense of the new socio-political reality that was taking shape in India ${ }^{28}$. In a world that was rapidly changing, new knowledge was necessary and learning English allowed Indians to have access to it. In fact, Indian intellectuals readily realised the global relevance of the $18^{\text {th }}$ and $19^{\text {th }}$ century revolutionary movements in France, Spain, Portugal, Latin America and Italy. Not surprisingly, the British were quite troubled. They were particularly anxious about the influence of the French Revolution, not only because the memory of it being a threat for the British Empire persisted, but also because they were aware that its egalitarian ideals were much more difficult to vanquish than any army. As a consequence, Fort St. William College was founded in 1800 with the main aim to become a bulwark against the erroneous principles of the Revolution. The depiction of Hinduism as a hierarchical religion became part of the project of propagating a social and political model of global inequality ${ }^{29}$.

17 Rammohan Roy, generally described as the father of the Bengal Renaissance, was the first eminent example of a cosmopolitan intellectual. Known also in Europe, Roy was a public man, deeply involved in the debates that were emerging at the global level around constitutional liberalism. He was committed in the spread of liberal ideas through the press, both in English and in Bengali, in order to create awareness among an Indian public opinion in the making. Roy appreciated the importance of modernity for the reform of society and was therefore an advocate of the introduction of a modern curriculum of studies for Indian students. He maintained that the study of 
ancient texts and Sanskrit was not suitable for the understanding of the changing world and promoted the adoption in the fledgling Indian school system of subjects such as history of Europe and India, geography, philosophy, geometry and arithmetic. Yet, in Roy's opinion, modernity did not imply the abandonment of tradition. Rather, it needed to be combined with tradition. So, a greater emphasis on reason did not necessitate rejecting religion. In fact, influenced by Christian humanitarianism, the founder of the Brahmo Samaj wanted to purify Hinduism of evil practices, like sati and child marriage, and make it more ethical and rational. Moreover, Roy gave historical corroboration to his demands for a constitution, for a free press, and for juries where his countrymen could serve. In fact, he wanted to demonstrate that, by invoking the introduction of such fundamental safeguards against the despotic and corrupt rule of the East India Company, he was not asking for alien institutions, because, on the contrary, these had already been part of ancient India. They simply needed to be revived according to spirit of the time ${ }^{30}$.

Also in the opinion of eminent social reformists like Ramakrishna Gopal Bhandarkar and Mahadev Govind Ranade ${ }^{31}$, espousing the principles of rationalism, Enlightenment and Humanism, did not run against India's own culture. Engaged in the effort to give dignity to the individual vis-à-vis the dictates of the castes, Bhandarkar found an historical justification for social reform, claiming that custom and religion were two different things and that, as a consequence, the old religious texts had to be interpreted according to the requirements of the times. Ranade agreed with this 'method of tradition' and tried to corroborate the importance of social reforms by using scriptural citations and the egalitarian teachings of the saint-poets of the bhakti tradition ${ }^{32}$. In polemic with the European critics who considered the 'oriental races' doomed to backwardness and even extinction unless they made way for the western spirit of social emancipation and religion, Ranade maintained that it was a peculiarity of the history of India to be reinvigorated after all invasions. In fact, "the nation (...) after a temporary submerging under the floods of foreign influences, has reared up its head - absorbing all that is best in the alien civilisation and polity and religions ${ }^{33}$. That process had always been a catalyser towards social evolution. In the same way, it would not be a break with the past, provided that the longed-for change "from credulity to faith, (...) from status to contract, from authority to reason, from organised to unorganised life, from bigotry to toleration, from blind fatalism to a sense of human dignity ${ }^{34}$ " occurred respecting the Indian cultural tradition. These reformists did not idealise the past, but relied on history to validate their projects of social reformation. The approach adopted by Ranade and Bhandarkar, while being a strategic way to involve the masses, was part of that wider process of societal reconstruction on the basis of the re-working of European ideas in the light of their local traditions: it is a clear example of the way Indians were shaping their own model of modernity by creatively intermingling values coming from their own tradition and values coming from the European one ${ }^{35}$.

19 The selective appropriation by Indian intellectuals of the thought of the most representative liberal thinkers must be inserted in this intellectual framework. Liberalism was not uncritically embraced, but adopted in such a way that it best fitted with the Indian demand for political and social inclusion. For instance, Aurobindo Gosh did not neglect to notice the limits of the French Revolution besides its undoubtable emancipatory aspects. According to the Bengali intellectual, freedom and equality would remain exterior, mechanical and unfounded without a change in the psyche of the people ${ }^{36}$. Furthermore, the fact that John Stuart Mill considered liberty as 
unsuitable for the barbarians, that is to say for the inhabitants of the colonies, was not even questioned by the Indians, but simply ignored, whereas Mill's stress on selfgovernment and education as means of progress was included in their discourse ${ }^{37}$. Again, those elements of liberalism that were not functional for the welfare of India were criticised and rejected. So, individualism was compensated with a greater attention to society and community, whereas the concept of secularism, as approved by the 1887 Indian National Congress, stressed the need on the part of the state to safeguard the balance among the different religious communities rather than being a political project aimed at over-imposing the creation of a secularised society ${ }^{38}$.

Note must also be taken of how the work of Edmund Burke was received in India. The well-known Reflections on the French Revolution ${ }^{39}$ became very popular in Indian colleges because the British considered it appropriate to counteract the effect of the revolutionary ideals. But Burke's stand on the French Revolution was not the only reason why the Irish philosopher captivated educated Indians. In fact, Burke had dealt with India during his long membership in the British Parliament and had compiled several parliamentary reports on the colony. He was deeply concerned with the nature of the Empire, which, in his view, was no less oppressive and violent than the French Revolution, since it had no respect for the previous social order of India. In Burke's words, the British colonisers, like the Jacobins, were incapable of transforming "the crude and ferocious impulses of conquest into the nobler and more sympathetic sentiments that link parents and children ${ }^{40 "}$. It is true that Burke's condemnation of the Empire originated from his anxieties that the East India Company parvenus, after having accumulated a huge wealth in India - Robert Clive was a notorious example could become members of Parliament and achieve social pre-eminence, regardless of hierarchy, traditional values or freedom ${ }^{41}$. However, Burke was also sincerely sympathetic with the people of India. Unlike both James and John Stuart Mills and other liberal thinkers, he thought that they were entitled to freedom, because freedom was attainable by all who desired it. What is more, Burke differed from John Seeley and John Strachey, because, unlike them, he recognised that all peoples had a sense of nationality and a sense of belonging to a territory, a natural feeling, but denied by the Empire $^{42}$. Therefore, it is not difficult to appreciate why Burke was an important source of inspiration for the Indian intelligentsia.

Burke represented a partial exception ${ }^{43}$ to the process of transformation of liberal ideas that, as shown by Mehta in his work on liberalism and Empire, was taking place in Great Britain. In the birthplace of liberalism, in fact, ideas that were supposed to have universal had the tendency to mutate in ambivalent and contradictory ways when getting in contact with the 'unfamiliar', namely with civilisations, that in the eyes of the British liberals, were backward and benighted. So, for instance, the interpretation of history differed according to the context to which it was applied; in the modern, rational West, history unfolded along the forward-looking line of progress, whereas in the other-worldly East, history was cyclical and entrapped in a timeless languor, until change and evolution were set in motion thanks to the encounter with Europe ${ }^{44}$. More importantly, according to the judgemental posture of liberal thinkers, the enjoyment of freedom was not suitable for backward peoples. Backward societies were languishing in a state of lethargy, because they did not possess the mental, cultural, and social preconditions to align themselves with progress. In the course of history, they had not been able to elaborate the concept of liberty and had thus remained excluded from the march of progress. Incapable of thinking of freedom, a fortiori they were unfit to enjoy 
it. This eternal torpor could be broken up only by the penetration of an external force. In this way, colonial power was justified as the factor that could bring material and moral amelioration to the peoples that had not been blessed by progress; it would provide them with the instruments of advancement so that they could finally achieve freedom in an undefined and far away future. This was the civilising mission of colonialism. In fact, according to the liberal outlook, the colonised status of the peoples was just temporary and would come to an end once such peoples would be ready for the achievement of freedom. However, when this day would come was never specified. In John Stuart Mill's view, Canada, New Zealand, and Australia had populations of "European races" and had reached a stage of civilisation similar to the English. Therefore, they were ready for representative government. On the contrary, other colonies, such as India, whose population was barbarous and uncivilised would not attain freedom for a long time. Here colonialism had to be benevolently authoritarian. Thus, the concept of liberty as a universally-sought and longed-for value was reconsidered and restricted to the advanced cultures. Liberal ideas became ambiguous, temporising, parochial. They denied equality and provided imperialism with a moral apologia. They failed to wield their liberating influence and turned into an ideology of oppression.

When, by the 1870s, Indian intellectuals started to ask for a greater participation in the administration and in the Councils, they were just demanding those political rights which, according to the British liberal tradition, they were entitled to. The liberal principles which, putatively, animated the foreign rulers were the same that inspired the founders of the Indian National Congress, who initially did not adopt a nationalist ideology, but were willing to help ameliorate the colonial rule by providing the Indian viewpoint and competence. Nonetheless, the scientific analysis of the political economy of the colonial state by eminent scholars like Mahadev Govind Ranade, Dadabhai Naoroji, Romesh Chandra Dutt, Ganesh V. Joshi and, at a later stage, Gopal Krishna Gokhale unveiled the predatory nature of the British rule. Their studies demonstrated that the Raj did not care for the Indian people's welfare, since its aim was the systematic draining of the resources of the subcontinent to the advantage of Great Britain and the creation of a market for British industrial products. After pointing out the specific characteristics of Indian reality, these 'dissenting economists' started to criticise the existing liberal economic paradigms and confuted that they could be universally applicable. Thus, in their opinion, the principle of laissez-faire was inadmissible in a weak economy such as the Indian one, where the state had to be both the guardian of the economic interests of the masses and the representative of the national will ${ }^{45}$. Moreover, in the opinion of the Indian critics of the Raj, free trade was a justification of the dominance of Great Britain over its colonies, so much so that they asked for economic protectionism. The Ricardian theory of rent, according to which the state in India played the role of landlord and had rights over the rent of the soil, was rejected and considered preposterous. Also the Malthusian explanation that blamed famines on overpopulation was rejected, because - it was argued - poverty in India was a man-made problem, a consequence of the land tax imposed by the colonial state ${ }^{46}$. Eventually, nationalist economic thought was unified within the framework of the "drain theory", articulated by Dadabhai Naoroji and Romesh Chunder Dutt ${ }^{47}$. The drain theory, which explained the state of poverty and dependence of India in such a way that every man could understand it, made people aware of the fact that their condition of degradation was the result of foreign domination. Therefore, Indian economic 
nationalists were the first to elaborate a comprehensive critique of colonialism, which would provide the ideological foundations of the anti-colonial movement for the following century.

By and large, there were several reasons why Indians at this stage of history found liberalism to be appealing. Substantially, it provided them with the political justification for the articulation of a nationalist discourse. In fact, the very foundations of liberalism could not condone imperialism, not only because imperialism implied oppression by the state, but also because, from the second half of the nineteenth century, the colonial discourse had been imbued with racism. So, it was no more possible for Indians to be redeemed thanks to the assimilation of the more advanced Western culture, since race made them permanently inferior. Indians, being the 'others' to the British, demanded their own national rights.

In addition, liberalism, with its emphasis on education, freedom and progress, was useful as a social programme to fight against those internal differences and inequalities, such as caste rigidities, communalism and a patriarchic order for which the colonial state could not be entirely blamed. Creating a fairer society rested on an overall change of the Indian mentality and could be achieved by finding a fruitful compromise between being an individual and being part of a certain community and by considering every human being, regardless of caste, religion and gender, worthy of respect and capable of moral, political, social and economic progress. But the nineteenth-century social reformers were aware of the fact that it was a long process, as changes of mentality always are. That is why they were captivated by the concept of gradualism, so common in liberal thought. The conviction that change had to be gradual was shared by all the Congress' founders. Social and economic development, in their view, were as important as freedom from British rule, but the two aims had to be brought together, because a free nation could not be founded on caste, gender and economic inequalities ${ }^{48}$. That is why the Congressmen believed in the emancipatory effect of self-government. In fact, the progressive extension of democracy would contribute to overcome the traditional social divisions, allowing a sense of common good and citizenship to be developed. In this sense, in the Indian context, the state should have an active role in creating freedom and equal opportunities; in the Indian reading, liberalism was not only absence of coercion by others, but it had also a constructive, positive drive ${ }^{49}$.

Ultimately, the social moderation inherent in liberalism suited the way Indian intellectuals envisioned society. In fact, they were a small social group, mainly coming from the urban bourgeoisie and the higher castes. Even though, as a rule, they were not wealthy, they were better-off compared to the poverty-stricken masses of peasants. According to traditional Indian culture, they perceived society as an organic, harmonious body, of which certain parts were fitter to occupy certain positions. So, even when they were in favour of the elevation of the masses, they did not want to rouse them against the colonial regime, since that would have perturbed the social equilibrium. For instance, according to Gokhale, "the sense of responsibility required for the proper exercise of the political institutions of the West can be acquired by an Eastern people through practical training and experiment only ${ }^{50 "}$. In other words, in the process of transformation of Indian society a sense of continuity and moderation was necessary not to lose trace of India's own past and tradition, on which the new institutions had to be accommodated. 
ale, disciple of Ranade, did not neglect the fact that political freedom without social freedom was inconsistent and weak. He understood that a powerful tool for the empowerment of the masses was education and he fought to make it free and compulsory at the primary level so that the conditions of the lower strata of society could be improved:

If you want to increase the wage earning capacity of the workmen, if you want the peasant to grow stronger and healthier and take better care of himself and understand his dealings with money lender and understand better his benefits of sanitation and agriculture, then compulsion alone had been proved effective in spreading education ${ }^{51}$.

Unfortunately, Gokhale's Education Bill was defeated also by the opposition of some nationalist leaders, in primis Tilak and his party, the so-called Extremists. What is interesting here is that the clash on the issue of an inclusionary education points out very clearly that those who fought for political freedom were not necessarily fighting also for social freedom ${ }^{52}$. In fact, the attitude towards the spread of education is a litmus test by which it is possible to understand what kind of nation the Indian leaders were imagining. As Parimala Rao argues: "the attempt to deny education to the poor, lower castes, and women ran parallel to the unequivocal demand for political independence by the same leaders. This leads to the question: Whose nation did they represent? (...) Was their demand for freedom aimed at essentially reinforcing a premodern feudal order or to build a modern nation state based on democratic principles ${ }^{33}$ ?"

\section{Gokhale's idea of the nation}

Gokhale's ideas are worth considering more closely ${ }^{54}$. Thanks to the popularity acquired as leader of the Indian National Congress, Gokhale could provide the all-India organisation with an 'authoritative statement' to show the world what Indians were suffering and what they wanted. He was, in fact, the first Indian politician and intellectual who elaborated a well-structured idea of the nation, predicated upon the application of the liberal principles which had been circulating in India for a century. The Gokhalean idea of the nation encompassed the main elements of the British political tradition of the seventeenth and eighteenth centuries, namely territorial unity, liberty and self-government. Among others, in Gokhale's opinion, John Stuart Mill had played an important part in moulding the 'new India ${ }^{55}$. Even though certain aspects of his thought were ignored because prejudiced against Asian societies, Mill's influence is very much felt in the speeches of Gokhale. But Gokhale's sources of inspirations were not only British. For instance, the argumentations made by Friedrich List in his National System of Political Economy ${ }^{56}$ found their way in some of the Budget speeches delivered by Gokhale in the Imperial Legislative Council ${ }^{57}$. Furthermore, List clearly formulated the liberal concept that a nation, in order to have historical justification, had to be of a certain size $\mathrm{e}^{58}$; this was an assertion which Indian nationalists, with their emphasis on territory, concurred with. But what is particular important in Gokhale's thought was the individual's will as part of the nation in the making. This concept was essential in the model of nation of Giuseppe Mazzini ${ }^{59}$. As a matter of fact, the Italian Risorgimento thinker held a fascination on Indians because the context in which he had operated appeared very similar to the Indian one. In other words, Italy, like India, having been divided in regional states for centuries, was a very 
heterogeneous polity; like India, it had been sacrificed in name of imperialism. Therefore, Mazzini underlined the importance of building the nation by looking at a common better future. Freedom was the only bond that would unite the people into a single whole. In other words, the lack of objective elements of cohesion would be overcome thanks to the commitment to build a free nation. In Mazzini's thinking, nationalism thus had to be transformed in a sort of secular and humanising religion: the national mission became a mission of divine origin, which did not clash with being part of the universal humankind. The Mazzinian inspiration is easily brought to our mind by the words of Gokhale:

The growth, during the last fifty years, of a feeling of common nationality, based upon common tradition, common disabilities and common hopes and aspirations, has been most striking. The fact that we are Indians first, and Hindoos, Mahomedans, Parsees and Christians afterwards, is being realised in a steadily increasing measure [...]. Public life must be spiritualised. Love of country must so fill the heart that all else shall appear as of little moment by its side. A fervent patriotism which rejoices at every opportunity of sacrifice for the motherland, a dauntless heart which refuses to be turned back from its object by difficulty or danger, a deep faith in the purpose Providence that nothing can shake - equipped with these, the worker must start on his mission and reverently seek the joy which comes of spending oneself in the service of one's country ${ }^{60}$.

The 'worker' was, in Gokhale's outlook, the educated Indian, 'the brain of the nation'. These Indians had 'cleared the jungle' and laid the foundations for the future work of political education and national advancement. Thanks to them, 'the idea of a united and renovated India' was no more an 'idle dream of a few imaginative minds ${ }^{61}$ '. Thus the role of education was double: it was pivotal as an instrument of social emancipation and in creating national consciousness.

Gokhale was aware of the fact that his national project could be accomplished only in the long run, along an arduous path, because the individual will of being part of the nation had to be built and enforced through a process of political and social maturation, in which both mass education and self-government should play a seminal role. So, he maintained:

Let us clearly bear in mind that any progress that we make as a people must now be on a democratic basis (...). And for this purpose, it is not a few towering individuals that will suffice, but the average strength of the mass of the people must be raised ${ }^{62}$.

31 An important turning point in the development of Gokhale's thinking was the government of Lord Curzon. In the opinion of the Indian leader, Lord Curzon's mandate, comparable only with Aurangzeb's despotic rule, had made it clear that 'equality [between British and Indians as per the proclamation of the British Parliament in 1833] has been a mere legal fiction ${ }^{63}$ '. In fact:

Lord Curzon, who dearly loves debating, thought it proper to attack the educated classes in regard to their constant reference to this Proclamation. He said in effect: "You base your claim for equality in the Queen's proclamation. But what does it promise you? It says that you will have equality when you are 'qualified' for it. Now, here we have certain qualifications which can only be attained by heredity or race. Therefore, as you cannot acquire race, you really cannot have equality with Englishmen in India as long as British rule lasts". Now (...) look at the unwisdom, the stupendous unwisdom, of the whole thing, telling the people of India that unless they were content to remain permanently a subject race in their own country, their interests and those of the British rule were not identical. After this, how can any Englishman complain if my countrymen regarded, as they have 
latterly regarding, your rule in India as maintained, not to promote their interests, but for a selfish purpose ${ }^{64}$ ? least not for the subject race. The disdain and contempt that British had towards India was justified by the fact that in the past "we [Indians] have shown no disposition to quarrel with despotic forms of government ${ }^{66 "}$. Ultimately, Gokhale found this view to be morally and politically unacceptable. He explained:

We could put up with it under the Mughals and in the Native states, because it was their form of government. They did not rule us in one way and themselves in another. But it is not your method and you cannot apply it to us without despising $\mathrm{us}^{67}$.

Therefore, Curzon's rule was a negation of the liberal principles which, as England had professed, would enable the Indian people to govern themselves according to the higher standards of the West ${ }^{68}$. It represented a dramatic change of course for the British policy until then pursued in India and embodied the triumph of centralisation and bureaucratisation of the Indian political system. Moreover, it excluded the educated classes, who alone were the real spokesmen and public opinion of the country. In short, it was not a responsible mode of governance, since nobody could be identified with the interests of the Indian people. Gokhale saw in the worsening of the political situation a consequence of the consolidation of the colonial power; the officials, supported by a well-structured and modern apparatus, did not need anymore the approval of the people and could show the real face of their domination ${ }^{69}$. What is more, not only had economic oppression turned into a permanent characteristic of the colonial rule, but also racial discrimination had become a systematic phenomenon, so much so that Indians had to live in a constant 'atmosphere of inferiority ${ }^{70}$ '. Racism towards Indians, both in the subcontinent and in South Africa, had become so pervasive that Indian people started to define themselves as the victims of that racial attitude ${ }^{71}$. So, in 1897, referring to the conditions of Indians in South Africa, Gokhale wrote that "after all, we are only British slaves, and not British subjects, and that it is idle on our part to expect justice or fair treatment where it does not suit the interest of Englishmen to be just or fair ${ }^{72 "}$. It was a folly, he said, to imagine that liberty and equality, the moral principles that occupied 'so prominent a place in the early creed of French Revolution' could be gifted by one nation to another ${ }^{73}$. The colonial racial posture became a criterion for the judgement of British attitudes towards their subjects. Deprived of its aura of benevolence, the despotic and racist British rule had turned into a violent midwife and could no longer vindicate a moral superiority over India and the eastern world in general. This realisation legitimised the revisitation of the orientalistic vision of history, namely the forced-upon image of a changeless and unresisting East. That traditional view:

[C]ould not go on forever, and the protest of the Eastern world against it, as evidenced by the steady growth of a feeling of national self-respect in different Eastern lands has now gathered sufficient strength and volume to render its continuance on old lines extremely improbable, if not altogether impossible. The victories of Japan over Russia, the entry of Turkey among constitutionally-governed countries, the awakening of China, the spread of the national movement in India, Persia and Egypt, all point to the necessity of the West revising her conception of the East - revising also the standards by which she has sought in the past to regulate her relations with the East $^{74}$. 
time had come to reset the power relations between 'West' and 'East' 'on more equal terms' and for India to retrieve its centrality on the historical stage. It was the beginning of that process of rewriting history that commonly runs parallel to the process of nation-building.

\section{Conclusion}

To conclude, the idea of the nation articulated by Gokhale was defined on the one hand by the principles of the British liberal tradition and on the other hand in contraposition to the illiberal British rule in India, which violated those same principles. Gokhale's conceptualisation of the nation was in sum a by-product of liberalism and its 'other'. In Gokhale's thought, liberalism was a safeguard against the oppressive colonial state, but it was also the catalyst for a radical social transformation against the internal evils of Indian society. It was liberty of each individual, regardless of his or her race, religion, class or caste. By adopting a political idea of nationhood which was opposed to an ethnic one, Gokhale articulated a form of nationalism that celebrated differences vis-àvis narrow identities and challenged the concept of nationhood - quite rooted in Europe by the end of the nineteenth century - according to which a country that did not possess blood and cultural bonds could not aspire to be a nation. This same argument was made by the civilians: India was a subcontinent, a territory, not a nation ${ }^{75}$. In short, the nation envisioned by Gokhale was inclusionary, individual-based, forward-looking, based on a common future in which economic and social discrimination would be finally overturned. It was predicated on an idea, rather than on external symbols. And exactly this was its weakness: being too rational and farsighted, it did not arouse deep and compelling passions. So, Gokhale's imagined nation was less appealing than the one of other nationalist ideologues, such as Tilak, in whose opinion, national consciousness had to revolve around the myth of a glorious Hindu, brahmanical past. According to Tilak, the intrusion of Western ideas had corrupted the ancient glory of India; the image of Shivaji was revisited and portrayed as that of a Hindu king who has defeated the Muslims "invaders"; old religious festivals were reintroduced in a new mass-dimension mould and politicised. Thus, Tilak's representation of the Indian nation was much more powerful, since it had the immediate advantage of mobilising people by means of a language easily understood by everyone. Nevertheless, it was divisive and dangerous, because it created a long-lasting sense of distrust between the majority, namely the Hindus - the real Indians - and the others. It was not liberal and, as such, did not advocate pluralism. Then, while fighting for freedom from the British, this new conceptualisation of nationalism did not promote national unity ${ }^{76}$. On the contrary, the Gokhalean concept of the nation, with its strong liberal component, demonstrates that, as Christopher Bayly held, "Indian liberalism was both wider in scope, and more specific in its remedies, than what is commonly called nationalism ${ }^{77 "}$. 


\section{NOTES}

1. K.M. PANIKKAR, The State and the Citizen, Bombay, Asia Publishing House, 1960 (first pub. 1956), p. 102.

2. This theory was formulated in Giorgio BORSA, Le origini del nazionalismo in Asia Orientale, (edited by G.C. Calza), Pavia, Università di Pavia, 1965, in Giorgio BORSA, La nascita del mondo moderno in Asia Orientale. La penetrazione Europea e la crisi delle società tradizionali in India, Cina e Giappone, Milano, Rizzoli, 1977, and in other works, among which the ones I will make reference to below. I am particularly thankful to Professor Michelguglielmo Torri, who has been personally benefitted by the scholarly advice of Giorgio Borsa, for his willingness to discuss at length Borsa's theory of modernisation. 3. Benedetto CROCE, La storia come pensiero e come azione, Bari, Laterza, 1938, p. 5.

4. Norberto воввіо, Liberalismo, in Dizionario di Filosofia, A. Biraghi (ed.),Milano, Comunità, 1957, p. 617-618.

5. See, among recent works, for example Annelien DE DIJN, French Political thought from Montesquieu to Tocqueville: Liberty in a levelled Society, New York, Cambridge University Press, 2008 ; Jeremy JENNINGS, Revolution and the Republic: A History of Political Thought in France since the Eighteenth Century, New York, Oxford University Press, 2011 ; Bryan GARSTEN (ed.), Rousseau, the Age of Enlightenment, and their Legacies, Princeton, Princeton University Press, 2012 ; Marie FoURCADE, Ines G. ZUPANOv (ed.), L'Inde des Lumières. Discours, Histoire, Savoirs (XVII ${ }^{e}$ XIX ${ }^{e}$ siècle), Editions de l'EHESS, 2013 ; Steven WALL (ed.), The Cambridge Companion to Liberalism, Cambridge University Press, 2015.

6. Eric новSBAwм, On History, London, Abacus, 1998 (first published 1997), p. 335.

7. Marie FOURCADE, Ines G. ZUPANOV, "Introduction. La question des Lumières en Inde : un champ à revisiter ?", in Marie FOURCADE, Ines G. ZUPANOV, L'Inde des Lumières, p. 13-49, here p. 29.

8. Which, of course, leaves the question open of what Asia is. Asia is not even a valid geographical expression, as pointed out by some geographers. See Martin W. LEWIS, Kären WIGEN, The Myth of Continents. A Critique of Metageography, University of California Press, Berkeley 1997. More importantly, Asia is not unified by a common culture/ civilisation. Between, e.g., Indian and Chinese civilisations the differences are as profound, and maybe more, than the ones setting apart e.g. Indian and European civilisation. A good starting point on this problem is William H. McNeill's classical work, The Rise of the West. A History of the Human Community, Chicago, University of Chicago Press, 1963. 'Asian Values', apart from being loosely based on Confucian ideology, are nothing different from a politically motivated fabrication.

9. The two historiographical schools often overlap in India. In fact, communism was perceived as an ideology conducive to provide post-colonial countries with an alternative kind of modernisation, distinct from the one offered by the capitalist mode of production. [Giorgio BORSA, "Nationalism and the Beginning of Modernisation in Eastern Asia/ Il Nationalismo e l'ingresso dell'Asia orientale nel mondo moderno", Il Politico (1964), p. 320-356, here p. 352].

10. Giorgio Borsa became promoter of a 'rivoluzione storiografica copernicana' that questioned both the Eurocentric and Asiacentric historiographies [Giorgio BORSA, "Dalla modernizzazione alla storia come conoscenza individuale", Pluriverso, 4 (1996), 
p. 116-127, here p. 117]. That his thesis is valid still today is confirmed by the fact that, of late, eminent scholars of India around the world have started elaborated a similar interpretation of the process of modernisation: Christopher A. Bayly, Sanjay Subrahmanyam and Sugata Bose are just some notable ones.

11. Giorgio BORSA, La nascita del mondo moderno, p. 10.

12. Ibidem.

13. Sanjay SUbRAhMANYAM, Is Indian 'Civilization' a Myth?, Delhi, Permanent Black, 2013, p. 6.

14. Eric HOBSBAWM, On History, p. 220.

15. See Michelguglielmo tORRI, Guido ABBATTISTA, Guido SAMARANI. "La nascita del mondo moderno in Asia orientale, di Giorgio Borsa.", Contemporanea 11 (1), 2008, p. 115-138, here p. 117-119.

16. See for example the essay by Ayesha JALAL, "Striking a just balance: Maulana Azad as a theorist of Trans-National Jihad." in Modern Intellectual History, p. 95-107 and Parimala V. RAO, Tilak's Nationalism: Discrimination, Education and Hindutva, Delhi, Orient Blackswan, 2010, infra.

17. Sharing certain ideological premises with the Marxists but focussing their analyses less on politics than on literature, the Subaltern Studies historiographic school have tried to give voice to the 'fragments' of the nation, the microstoria of the people who had been left out by the nationalist narrative. Both Marxist and 'Subaltern' schools repudiate liberalism as the core ideology of imperialism, as something cunningly concealing the real nature of the colonial rule. Those Indian politicians and thinkers who used liberal ideology to criticise the colonial government are regarded with contempt as compradores of the regime, just willing to defeat the foreign domination in order to replace them to the detriment of the common Indian man.

18. This attitude of the Indian nationalist historiography is countered by the apologetic attitude towards imperialism and the revival of certain myths of the old colonial historiography, which are distinguishing features of a not inconspicuous strand especially in US and British historiography (see Niall Fergusson's constant justification of British and American imperialism).

19. For the post-independence Indian historiography see Michael GOTTLOB (ed.), Historical Thinking in South Asia. A Handbook of Sources from Colonial Times to the Present, Delhi, Oxford University Press, 2003, p. 1-87 and p. 217-284; Michael GOTTLOB, History and Politics in Post-colonial India, Delhi, Oxford University Press, 2011, infra.

20. See Michelguglielmo TORRI, Regime coloniale, intellettuali e notabili in India. Politica e società dell'era del nazionalismo, Milano, Franco Angeli, 1996, p. 19-61, in which the author elaborates a sophisticated critique of the historiography of the Cambridge school. Part of this critique is available in English. See Michelguglielmo TORRI, “"Westernized Middle Class», Intellectuals and Society in Late Colonial India”, Economic and Political Weekly, Vol . XXV, No. 4, 27 January 1990.

21. See the special issue of Modern Intellectual History, 4, 1 (2007); Christopher A. BAYLY, Recovering Liberties. Indian Though in the Age of Liberalism and Empire, Delhi, Cambridge University Press, 2012; Sugata BOSE, A Hundred Horizons: the Indian Ocean in the Age of Global Empire. Harvard University Press, 2009; Andrew S. SARTORI, Liberalism in Empire. An alternative History, Berkeley, University of California Press, 2014.

22. Christopher A. BAYLY, "Liberalism at Large: Mazzini and Nineteenth-century Indian Thought", in Christopher A. BAYLY, Eugenio F. BIAGINI (ed.), Giuseppe Mazzini and the 
Globalisation of Democratic Nationalism (1830-1920), Oxford University Press for the British Academy 2008, p. 355-374, here p. 355.

23. Shruti KAPILA, "Preface", in Modern Intellectual History, p. 3-6, here p. 4.

24. Christopher A. BAYLY, Recovering Liberties..., op.cit., p. 173. In the words of B. B. Majumdar, "it has been the British domination - and therein lies the peculiar merit of it - that has slowly roused India to a new political consciousness. and once again after six centuries, a development of political thought has taken place through criticism and appreciation of the British administrative system in all its different and expanding spheres, for that is the only way in which political thought can grow in a subject country, as it grew in the subject medieval countries of Central Europe through discussion of questions affecting the Papal and Empire governments" (in B.B. MAJUMDAR, History of Indian Social and Political Ideas. From Rammohan to Dayananda (1821-84), Calcutta, Bookland, 1967, p. V). This work, first published in 1934, was the last to deal with the history of political thought in India for a long while.

25. Christopher A. BAYLY, Recovering Liberties, op.cit., p. 10.

26. Bangavasi, Calcutta, 2 January 1909, in Native Press Reports (NPR), National Archives of India (NAI).

27. See ahead.

28. Significantly enough, when the colonial government introduced English as the language of higher education, it was mainly thanks to the initiative of Indians, often with the individual support of few British liberals and missionaries, that English schools were established (Rao, History of Indian Education, 20). See also Antonio RECUPERO, "Macaulay, l' "interpretazione whig della storia" e l'istituzione della lingua e dell'istruzione inglese in India (1813-1835)", in Le Carte e la Storia, 9.2 (2003), p. 47-57. 29. Kapil RAJ, "L'Orientalisme en Inde au tournant du XIX siècle : La Réponse du mondialisme britannique a l'universalisme de la Révolution francaise", $A H R F, 320$ (2000), p. 89-99, here p. 92-93.

30. See Christopher A. BAYLY, "Rammohun Roy and the Advent of Constitutional Liberalism in India, 1800-1830", Modern Intellectual History, p. 25-41, infra. The theme of constitutional monarchy as part of the political system of ancient India is recurring in several future nationalist authors, especially after the discovery of the Chanakya's Arthashastra. An example is the work of the historian K.P. Jayaswal (1871-1937) published in the Modern Review of Calcutta [See Claude MARKOVITS, "L'Inde colonial : nationalisme et histoire", Annales (1982): p. 648-668, here p. 653].

31. They were active in the Bombay presidency where the influence of European ideas had been felt very early thanks to the reform of the educational system introduced by the governor Mountstuart Elphinstone (1819-27). Significantly, Ranade was the political guru of Gopal Krishna Gokhale.

32. Aravind GANACHARI, Gopal Ganesh Agarkar: The Secular Rationalist Reformer, Mumbai, Popular Prakashan, 2005, p. 19-20.

33. Sudharak (Reformer), "Social Evolution”, 16 October 1893.

34. Ibidem.

35. It is worth taking note of the fact that a process of restoration of orthodox, brahmanical Hinduism ran parallel to the process of its reformation. As a matter of fact, the aggressive discourse of Christian missionaries strongly contributed to make the local religions feel jeopardised and threatened. The reaction of Hindu religious reformers was the attempt to rationalise and simplify Hinduism, which had been until then a polymorphous aggregate of many religious traditions rather than a 
homogenous, monotheistic religion stricto sensu. Therefore, Hindu reformers selected the system of thought of few Hindu traditions - generally those close to Brahmanical worship because it was to brahmanical castes that these intellectuals belonged - in order to provide Hinduism with elements of coherence and uniformity so that it could turn into an authoritative and powerful counterweight to challenge the intrusiveness of Christianity. Unfortunately, Muslims too became target of the new aggressive posture acquired by Hinduism. Hindu militancy manifested itself also with a strong proselytising action in order to reduce conversions to Christianity but also to bring Hindus converted to Islam back to the fold of the new mould of Hinduism. Religion, then, was transformed into a polarising factor between religious communities. So, for example, the ban on cow-slaughter promoted by the Hindu revivalist Arya Samaj spurred tension and hostility between Muslims and Hindus. See Romila THAPAR, “ Imagined Religious Communities? Ancient History and the Modern Search for a Hindu Identity", Modern Asian Studies, 23 (2), May 1989, p. 209-231.

36. Rita D. SIL, "Images de la Revolution Francaise dans la Colonisation et la Decolonisation en Inde", in Michelle Vovelle (ed.), L'Image de la Révolution Française, Pergamon Press, 1989, p. 1812-1822, here p. 1815.

37. That is why Gopal Krishna Gokhale cited Mill's work on the representative government, rather than On Liberty. See, for example, the speech delivered by Gokhale in the Bombay Legislative Council on the Mofussil Municipalities Bill, February 1901, R. P. PATWARDHAN, D. V. AMBEKAR (ed.), Speeches and Writings of Gopal Krishna Gokhale, Volume 2, Poona, Deccan Sabha, Asia Publishing House, 1966, p. 114-134, here p. 121.

38. As Nehru held in 1961, a secular state was "a state which honours all faiths equally and gives them equally opportunities" [quoted in T.N. MADAN, "Secularism in Its Place", The Journal of Asian Studies, Vol. 46, N 4 (Nov. 1987), p. 747-759, here p. 756].

39. Edmund Burke, Reflections on the French Revolution, London, Penguin 1968.

40. Uday Singh MEHTA, Liberalism and Empire. A Study in Nineteenth-Century British Liberal Thought, London, University of Chicago Press, 1999, p. 140.

41. Uday Singh Mehta, Liberalism and Empire, op.cit., p. 172-173.

42. Uday Singh Mehta, Liberalism and Empire, op.cit., p. 133-149. See Edmund Burke, "Speech on the State of Representation of Commons in Parliament", in J.F. Taylor (ed.), Writings and Speeches, New York, Little Brown, 1901, (7), p. 94-95.

43. As a matter of fact, also in Burke's thought there were elements of ambiguity. See for instance the contribution by Sunil AGNANI, "India and Haiti as Colonial Spaces of the Enlightenment", in Marie FoURCADE, Ines G. ZUPANOv, L'Inde des Lumières, op.cit., p. 189-208. According to Agnani "Burke is sharply critical of the equivalent of the "planters", namely the East India Company officials who are viewed as akin to revolutionary Jacobins, heedlessly transforming the social fabric of a society. But in the West Indian context he is in league with this class of planters and fears what he calls the "race of fierce barbarians" (namely, the West-African born soldiers and insurgents of St. Domingue) who are allied with the French" (Ivi, p. 200-201).

44. See also Prathama BANERJEE, "Time and Knowledge", in Pradip Kumar DATTA, Sanjay PALKISHAR (ed.), Indian Political Thought, Delhi, Oxford University Press, 2013, p. 28-62, here p. 56.

45. Bipan CHANDRA, The Rise and Growth of Economic Nationalism in India, Economic Policies of Indian National Leadership 1880-1905, Delhi, Har-Anand Publication, 2010 (first published 
1966), p. 639. See also K.M. PANIKKAR, In defence of liberalism, Bombay, Asia Publishing House, 1962, p. 14.

46. Jayati GHOSH, "Dissenting Economists. The late nineteenth-century Indian tradition", in Claudio SARDONI, Peter KRIESLER (ed.), Keynes, Post-Keynesianism and Political Economy, Essays in Honour of Geoff Harcourt, Vol. 3, London, Routledge, 1999, p. 94-109, here p. 97-98.

47. Jayati GHOSH, “Dissenting Economists”, op.cit., p. 102.

48. Since the foundation of the Congress, its leadership decided that the pursuit of social reforms was not responsibility of the party. Instead, the battle against social evils had to be carried out by other organisations, such as, for instance, the Servants of India Society, created by Gopal Krishna Gokhale.

49. I have benefitted from the insightful and much-appreciated critical comments made upon the first draft of this article by an anonymous reviewer who observed that the way liberalism was adopted in, and adapted to, the colonial context by Indians was very similar to French republicanism. In fact, the republican visions were more insistent on equality and common good, and intermingled with democratic, liberal and socialist perspectives. Compared to British liberalism, moreover, French liberalism had a preference in articulating the defence of liberty grounding it on natural rights instead of utilitarianism, something which was appealing to Indians. There is still much that remains to be explored in this field. It could be argued that French republicanism was significant to Indians because it was the 'other of the other' and could play an important role in the political and intellectual needs of the anti-colonial discourse, in the same way as Thomas Paine's Common Sense and The rights of Man did. The political thought of the French republicanism has kindled increasing interest in the past twenty years. Among others, some recent works are: Mona Ozouf, “L'idée républicaine et l'interprétation du passé national", Annales, 53 (1998), p. 1075-87; Philip PETTIT, Republicanism: A Theory of Freedom and Government, Oxford, Oxford University Press, 1997; Jeremy JENNINGS, Iseult HONOHAN (ed.), Republicanism in Theory and Practice, London, Routledge, 2005; Jeremy JENNINGS, “Citizenship, Republicanism and Multiculturalism in Contemporary France”, British Journal of Political Sciences, 30, 4 (2000), p. 575-598;. Nadia URBINATI, "Republicanism after the French Revolution: The Case of Sismonde de Sismondi", Journal of the History of Ideas, 73, 1(2012), p. 95-109. It would be interesting to insert French Republicanism in the frame of global intellectual history, further contributing to the work done by Marie FOURCADE, Ines G. ZUPANOV, L'Inde des Lumières, op.cit.

50. Speeches and Writings of Gokhale, Volume 2, p. XXVII. Italic added.

51. The Mahratta, "Elementary Education Bill objections answered. Hon. Mr Gokhale's speech", 30 July 1911, p. 397-369.

52. This has been underscored very well by the work of Parimala V. Rao. See Parimala RAO (ed.), New Perspective on the History of Indian Education, Delhi, Orient Blackswan, 2014; the above mentioned Tilak's Nationalism: "A Century of Consolidation and Resistance. Caste and Education in Maharashtra (1818-1918)". History and Society, Occasional Paper n.54, Delhi, Nehru Memorial Museum and Library, 2014. Gokhale always paid a great deal of attention to social justice in his public speeches all over his political life. His view was very progressive, as we can see from an excerpt of a lecture delivered in Madras: "The humanitarian movement of the eighteenth century in the West has done more for the people pf the West in some respects than ever their struggle for their political freedom. if we understand correctly the value of the dignity of man as man, if 
we understand the value of the social freedom, if we understand the injustices and the disabilities placed upon any section on the score of birth and sex, if we understand all these things correctly, if we are fired by that enthusiasm which always comes from a keen sense of injustice, if we put our shoulders to the wheel and try to set some matters right, then I say we shall have done something in the social and humanitarian sphere. A beginning has been made and there is an awakening in this land such as there never was. We are at any rate ashamed of many of the social injustices which we deplore on all sides of us; only we do not take up with energy, necessary energy, the work to remove those injustices" (Gopal Krishna Gokhale, Responsibilities of Public Life. A lecture delivered by Mr. G.K. Gokhale in Madras, Madras, Sons of India, 1917, p. 4-5. This speech was printed as part of the project promoted by Annie Besant and her Home Rule League aimed at the political sensitisation of Indian people over some relevant social and political issues.

53. Rao, History of Education, p. 36.

54. The best biography of Gokhale is Bal Ram NANDA, Gokhale: the Indian moderates and the British Raj, New Jersey, Princeton University Press, 1977.

55. Gokhale Papers, NAI, From Gokhale to John Morley, 9th May 1897.

56. Friedrich LIST, The National System of Political Economy, London, 1885. List took part in the debates of economic development in 1820s in the United States of America and was inspired by Hamilton's Outline of American Political Economy (Philadelphia, 1827). The purpose of national economy in List's opinion was to encourage capitalist industrialisation.

57. See "Import Duty on Sugar", in R. P. PATWARDHAN, D. V. AMBEKAR (ed.), Speeches and Writings of Gopal Krishna Gokhale, Poona, Deccan Sabha, Asia Publishing House, Vol, 1, 1962, 9th March 1911, p. 335.

58. See Eric новSваWм, Nations and Nationalism since 1780, Cambridge, Cambridge University Press, 1990, p. 30.

59. Although he never mentioned Asia in his writings, Mazzini became very popular in India and his works were translated in several Indian languages. The reading of Mazzini by Indian ideologues is very interesting and it shows how the thought of the Italian nationalist was adopted by very different strands of Indian nationalism. See Gita SRIVASTAVA, Mazzini and his Impact on the Indian National Movement, Allahabad, Chugh Publications, 1982 (especially chapters VII-X) and the more recent essay by Christopher A. BAYLY, "Liberalism at large". Mazzini's conceptualisation of the nation was similar to the one formulated by Ernest Renan, expressed by the latter in 1882 in the lecture "Qu'est-ce qu'une nation?" Here the French historian defined the nation as a 'plébiscite de tous les jours' (See Ernest RENAN, Oeuvres complète, Paris, Calmann-Lévy, 1947, p. 887-906, here p. 904). For Mazzini's definition of the nation see Federico CHABOD, L'Idea di Nazione, Bari, Laterza 2011 (first published 1967), p. 80-91.

60. G. A. NATESAN (ed.), Speeches of Gopal Krishna Gokhale, Madras, Natesan, 1920, p. 915. This was the speech delivered in occasion of the inauguration of the Servants of India Society, founded by Gokhale in 1905 . The society had the purpose to unite and train Indians in welfare work, so that the masses could be provided with elements of selfelevation and be more readily included in the national project. The constitution of the organisation (See Bal Ram NANDA, Gokhale..., op.cit, p. 169-176) was a real national programme and the servants, a sort of political sanyasin, had to circulate Gokhale's idea of the nation.

61. Ivi, p. 914. 
62. Speech on the Education Bill addressed by Gokhale in the Calcutta Town Hall on the $2^{\text {nd }}$ September 1911, in D. G. KARVE, D. V. AMBEKAR (ed.), Speeches and Writings of Gopal Krishna Gokhale, Volume 3, Poona, Deccan Sabha, Asia Publishing House, 1967, p. 244. 63. Speech of Gokhale at the New Reform Club, 14th November 1905, in R. P. PATWARDHAN, D. V. AMBEKAR (ed.), Speeches and Writings of Gopal Krishna Gokhale, Volume 2, p. 334.

64. Ibidem.

65. "Congress Presidential Address", Benares 1905, in R. P. PATWARDHAN, D. V. AMBEKAR (ed.), Speeches and Writings ..., Volume 2, p. 190.

66. R. Gordon MILBURN, England and India, London, George Allen and Unwin Ltd, 1918, p. 18. See in particular the second chapter (p. 17-22), where the author reports a talk he had with Gokhale.

67. R. Gordon MILBURN, England and India, op.cit., p. 18.

68. Speech by Gokhale at the New Reform Club, 14th November 1905, in Speeches and Writings of Gokhale, Volume 2, p. 337.

69. Speech by Gokhale at the New Reform Club, $14 \mathrm{t}^{\mathrm{h}}$ November 1905, in Speeches and Writings of Gokhale, Volume 2, p. 337-339.

70. Gopal Krishna GOKHALE, “Welby Commission Written Evidence”, 1897, in R. P. PATWARDHAN, D. V. AMBEKAR (ed.), Speeches and Writings of Gopal Krishna Gokhale, Volume 1, p. 488.

71. See David oMISSI, "India: Some Perceptions of Race and Empire”, in D. OMISSI, A. S. THOMPSON (ed.), The Impact of the South African War, Basingstoke, Palgrave 2001, ch. II; especially p. 219-20, p. 27).

72. "British Indians in South Africa", article by Gokhale appeared on India, June 1897, Speeches and Writings of Gokhale, Volume 2, p. 399.

73. Ibidem.

74. Gokhale, "East and West in India", paper read at the Universal Races Congress held in London, in Speeches and Writings of Gokhale, Volume 2, July 1912, p. 380.

75. It is interesting to note that the argument made by the civilians was in contrast with the English concept of the nation. In fact, in England, the idea of the nation in the modern meaning of the term was predicated on territory. In other words, all those who were born in England were members of the English nation.

76. On Tilak see Richard I. Cashman, The myth of the Lokamanya: Tilak and mass politics in Maharashtra, Berkeley, University of California Press, 1975; Parimala V. RAO, Tilak's Nationalism..., op.cit. For a comparison between Tilak and Gokhale see Stanley A. WOLPERT, Tilak and Gokhale: Revolution and Reform in the Making of Modern India, Delhi, Oxford University Press, 1989 (first published 1962).

77. Christopher A. BAYLY, Recovering Liberties, p. 1. 


\section{ABSTRACTS}

This essay wants to show how educated Indians appropriated and reshaped the liberal ideology of their colonisers, the British, during the nineteenth century. Liberal ideas were adapted to a situation utterly different from the European one and creatively combined with indigenous ideas. This was part of a wider process of re-working European ideas in the light of Indian traditions in order to formulate an autonomous model of modernity. Against some current critiques of liberalism which see it as the ideological 'cover' for inequality and imperialism, this essay attempts to show that, in the colonial context, Indian liberalism offered a powerful critique of colonialism and emphasised collective identity and equality more than British liberalism did. The example of Gopal Krishna Gokhale, leader of the Indian National Congress, is dealt with to explain how certain Western ideas provided the foundation to elaborate an idea of the nation in the modern meaning of the term.

Cet essai veut montrer comment les Indiens cultivés, au cours du XIX ${ }^{\mathrm{e}}$ siècle, se sont appropriés et ont remodelé l'idéologie libérale de leurs colonisateurs britanniques. Les idées libérales ont été adaptées à un contexte tout à fait différent de celui de l'Europe et combinées d'une manière créative à la pensée autochtone. Cela faisait partie d'un processus plus vaste de reformulation des idées européennes à la lumière des traditions indiennes, dans le but de créer un modèle autonome de modernité. Contre certaines critiques contemporaines du libéralisme, qui le considèrent comme une "couverture » idéologique des inégalités et de l'impérialisme, cet essai tente de montrer comment le libéralisme a offert une critique puissante du colonialisme, en soulignant tant les identités collectives que l'idée d'égalité (d'une manière bien différente de l'idéologie libre-échangiste britannique). On a traité ici l'exemple de Gopal Krishna Gokhale, chef du Congrès National Indien, pour montrer comment certaines idées occidentales ont fourni la base pour élaborer, en Inde, une idée de Nation dans le sens moderne du terme.

\section{INDEX}

Mots-clés: Libéralisme, Idée de Nation, Nationalisme, modernité, Gokhale

Keywords: Liberalism, Idea of the Nation, Nationalism, Modernity, Gokhale

\section{AUTHOR}

\section{ELENA VALDAMERI}

PhD candidate

State University of Milan - Department of Historical Studies 